\title{
Review: A Region of France
}

Source: The Geographical Journal, Vol. 36, No. 2 (Aug., 1910), pp. 205-206

Published by: geographicalj

Stable URL: http://www.jstor.org/stable/1777700

Accessed: 06-04-2016 21:11 UTC

\section{Your use of the JSTOR archive indicates your acceptance of the Terms \& Conditions of Use, available at}

http://about.jstor.org/terms

JSTOR is a not-for-profit service that helps scholars, researchers, and students discover, use, and build upon a wide range of content in a trusted digital archive. We use information technology and tools to increase productivity and facilitate new forms of scholarship. For more information about JSTOR, please contact support@jstor.org.

The Royal Geographical Society (with the Institute of British Geographers), Wiley are collaborating with JSTOR to digitize, preserve and extend access to The Geographical Journal 
an apparatus of which the recording part was an ordinary barograph drum, the scale being reduced by means of a long lever. Besides the tides the record indicated seiche oscillations. The scale of the recorded curve was so small that the seiche festooning was blurred, but by watching the apparatus for some time it was seen that in calm weather there were seiches having a period of several minutes and an amplitude of several inches.

In biology the greatest interest lies in the discovery of abundant fresh-water microscopic life in the frozen lakes, despite the fact that these only thaw for a short period in summer, and some of them only at long intervals. Even in a lake which never melted while we were there, there were many living animals on the bottom, under 15 feet of ice. The adult animals survive from season to season in a dormant, condition, frozen in the ice.

Several are viviparous, and those are the most plentiful of all. Their abundance would be remarkable in any latitude. In the few weeks of summer one of them increases so rapidly that it makes blood-red stains on the beaches of the lakes, and these attain to inches in diameter. They can endure great vicissitudes of temperature, and some have lived after being made to pass in a short time through a range of $240^{\circ} \mathrm{Fahr}$. The whole range endured by one species was over $300^{\circ} \mathrm{Fahr}$., but the same individuals were not submitted to both heat and cold.

The composition of the fresh-water microfauna, which is not very abundant in species, is of great interest. Its negative as well as its positive characters raise many curious questions in geographical distribution.

In marine biology it is instructive to note that all the cold-blooded animals pass their entire lives at a temperature which is always several degrees below the freezing-point of fresh water, and that this temperature is therefore high enough for the performance of all their physiological functions.

\section{REVIEWS. EUROPE.}

\section{a Region of France.}

' Le Var Supérieur. Etude de Géographie Physique.' Par Jules Sion, Ancien Éleve de l'École normale supérieure, Docteur ès Lettres. Pp. 96. Paris: Colin. [1909.] Price 3 fr.

THIs is one of those detailed studies in physical geography which are now becoming so numerous and which illustrate the action of natural forces under varying conditions. The region chosen is the upper valley of the Var above the affluents descending from the massive of the Mercantour, an area of nearly 45 square miles. Further south the river meanders through a pebbly plain in a bed recently eroded in an immense Pliocene delta.

The author first describes the movements of the soil, the foldings which took place before the Permian age and at the conclusion of the Secondary period, the invasion of the Miocene sea and the elevation of the Miocene beds and also of the Pliocene, the latter to a height of about 1800 feet at Levens, while along the littoral of Nice Quaternary deposits occur at a height of about 190 feet above sea-level. A study of the structure shows that the hydrography in the upper basin of the Var often does not accord with the tectonique: the river often runs in a direction contrary to the dip of the strata, crosses anticlinal ridges, cuts into the flank of the Dôme de Barrot, which is traversed by one of its tributaries, the Cians, and even when it follows a synclinal basin, it remains at a distance from the axis of depression. 
In the section Saint-Martin-Guillaumes-Enriez, which the author calls the "Var de Guillaumes," the river skirts such a synclinal depression, and formerly it terminated in the Annot hollow, but was subsequently captured by the "Nar de Tonët," which is guided by a synclinal area below Entrevaux. How the present hydrographical system has been formed in all probability - for many details have not yet been fully demonstrated-is explained in this work, and there are also chapters on the torrential réyime and deforestation with its disastrous effects.

A great defect is the absence of maps. Orographical and geological maps, however crude, would assist the reader, to whom the maps referred to by the author may not be easily accessible, in understanding the text.

'Les Grands Ports de France.' By Paul de Rousiers. (Paris : Armand Colin. 1909. 3.50 fr.) A monograph on the economic conditions of the ports of France. The author examines each instance from three points of view. (1) Regional: The capacity of a port for affording access to a hinderland. (2) Industrial : Convenience for trade; customs and regularity of traffic. (3) Convenience for maritime trade. Many ports, as Le Havre, fall under all three divisions; others under one only. Dunkerque is almost entirely regional. Rouen depends mostly on its traffic with the Paris basin. The commercial history of the ports is interestingly described, and their present trade and advantages discussed in a series of chapters devoted to the several ports. The book should be of value to students of economics.

'Cornwall.' By S. Baring Gould. ("Cambridge County Geographies" Series. Cambridge: University Press. Pp. ix., 164. Maps and Illustrations. 1s. 6d.) The series maintains its standard of excellence in this volume-of this the author's name should be sufficient guarantee. When so many different writers have contributed to the series, it is good to see the close editorial control that has been maintained over all, so that the uniformity of the series does not suffer.

'The Marlborough Country.' By H. C. Brentnall and C. C. Carter. (Pp. 77. Diagrams.) This memoir on shet 266 of the 1 -inch Ordnance Survey has been written for the use of Marlborough college, and sets an example which might well be followed. It teaches the study of topography and land-forms in connection with the map, and it pays particular attention to the monuments of antiquity (Avebury, Silbury, and a host of others less well known) with which the district abounds.

\section{ASIA.}

The Garos of Assam.

'The Garos.' By Major A. Playfair, I.A. With an Introduction by Sir J. Bampfylde Fuller, k.c.s.I., o.I.E. (Published under the Orders of the Government of Eastern Bengal and Assam.) With Illustrations and Maps. Pp. xvi., 172. London: Nutt. 1909. Size $8 \frac{1}{2} \times 5 \frac{1}{2}$. Price 78. $6 d$.

This book is another volume of the excellent series of monographs on the tribes of Assam, which is being issued under the auspices of the Government of the province. The plan and arrangement of the earlier works have been strictly followed in this volume-that is to say, there are sections on the People, their habitat and affinities, Domestic Life, Laws and Customs, Religion, Folk-lore, and Language.

The Garos inhabit, in the main, the range of hills on the west of Assam, but they are also found sporadically distributed over other parts of the province. A branch of the great Tioeto-Burman family, they have migrated, in common with other tribes, from the region of the Himalayas, and Major Playfair has been furtunate enough to recover some of their traditions regarding these wanderings. Like the 